

\section{No evidence of antiseptic properties and low toxicity of selected Aloe species}

\author{
L. Mpala ${ }^{1}$, G. Chikowe ${ }^{1}$, \\ I. E. Cock ${ }^{1,2}$
}

${ }^{\text {I} B i o m o l e c u l a r}$ and Physical Sciences, Nathan Campus, Griffith University, 170 Kessels Road, Nathan, Brisbane, Queensland 4111, ${ }^{2}$ Genomics Research Centre, Gold Coast Campus, Griffith University, Parklands Drive, Southport, Queensland 4222, Australia

DOI: $10.4103 / 0976-9234.68869$

\begin{abstract}
Background and Aim: Closely related plant species often share similar secondary metabolites and bioactivities and are therefore good targets for bioactivity testing when one or more species within a genus are known to possess therapeutic properties. The genus Aloe has a long history of medicinal usage in many areas of the world. Many species are known to have therapeutic properties, several species of which have wellestablished antibacterial bioactivities. The current studies examine the toxicity of several Aloe species and their ability to inhibit bacterial growth and compare them to the most extensively studied species, Aloe barbadensis, which has well-established antibacterial bioactivities. Results: $A$. barbadensis methanolic extract displayed broad spectrum antibacterial activity, inhibiting the growth of 8 of the 14 bacteria tested $(57 \%)$. It was effective against both Gram-positive and Gram-negative bacteria, inhibiting the growth of 4 of 4 Gram-positive bacteria (100\%) and 4 of 10 Gram-negative $(40 \%)$ bacteria tested, respectively. In contrast, Aloe elgonica, Aloe pruinosa, Aloe chabaudii, Aloe daiyana, Aloe marlothi and Aloe vryheidensis all showed no antibacterial activity toward any of the bacteria tested. All of the Aloe species displayed low toxicity similar to that of the A. barbadensis control. A. daiyana was the most toxic of the Aloe species tested with 24,48 and 72 hours LC50 values of $1018.2,517.0$ and $405.7 \mu \mathrm{g} / \mathrm{ml}$, respectively. Conclusions: Despite their close taxonomic relationship, $A$. elgonica, $A$. pruinosa, A. chabaudii, A. daiyana, A. marlothi and $A$. vrybeidensis do not have the same antibacterial medicinal potential as $A$. barbadensis, but may still have other similar toxicity-related bioactivities. Testing against protozoa, fungi, virus and tumor cells is required to determine if this is the case.
\end{abstract}

Key words: Aloe barbadensis Miller, Aloe vera, antibacterial, medicinal plants, methanolic extracts, phytotoxicity

\section{INTRODUCTION}

The use of natural plant therapeutics is as old as human civilization and in many regions of the world is still the primary modality of health care. Ayurvedic medicine in India, for example, is still commonly practiced, with approximately $85 \%$ of Indians using crude plant preparations for the treatment of various diseases and ailments. ${ }^{[1]}$ Even in Western civilizations, plants play an important role in medicine. At least $25 \%$ of pharmaceuticals prescribed worldwide are directly obtained from plants with many more drugs being semi-synthetic derivatives of natural plant precursors..$^{[2-4]}$ Examples of medicinally important plant-derived compounds include the anti-malarial drug quinine and its derivatives (from Cinchona spp.), the antitumor drugs vincristine and vinblastine (from Catharanthus roseus) along with the semisynthetic analogue vindesine, the analgesics morphine and codeine (from Papaver somniferum), the anticholinergic drug atropine derived from plants of the family Solanaceae (Atropa belladonna, Datura stramonium and Mandragora officinarum), the anticancer drug taxol (derived from Taxus brevifolia) and the cardiac glycoside digoxin (from Digitalis purpurea). ${ }^{\left[{ }^{[5]}\right.}$

Despite the potential of plants to provide us with useful pharmaceutical agents, the field is still poorly studied. Only an estimated $5-10 \%$ of the approximately $300,000-500,000$ plant species worldwide have been screened for one or

Address for correspondence:

Dr. Ian Cock, Biomolecular and Biomedical Sciences, Nathan Campus, Griffith University, 170 Kessels Road, Nathan, Brisbane, Queensland 4111, Australia. E-mail: I.Cock@griffith.edu.au 
more bioactivities. ${ }^{[5]}$ With so many plant species yet to be tested, it is essential that plant selection processes narrow the field. The main selection criterion currently used is to select plants on the basis of their ethnobotanical usage as traditional medicines. Another important selection method is to examine plants closely related to plants for which medicinal potential is well established. Many plant secondary metabolites are regarded as family-, genus- or species-specific and investigation of species closely related to those used as traditional medicines may lead to natural therapeutic discovery. ${ }^{[2]}$

Plants from the genus Aloe (family Asphodelaceae) have a long history of medicinal use in the treatment of a wide variety of medical disorders and conditions. Four species, specifically Aloe barbadensis Miller (commonly known as Aloe vera) ${ }^{[6]}$ Aloe ferox (Cape Aloe), ${ }^{[7]}$ Aloe arborescens (Candelabra Aloe $)^{[8]}$ and Aloe perryi baker (Perry's Aloe), ${ }^{[0]}$ have had their ethnopharmacological usage particularly well documented. Of these, $A$. barbadensis has been the most extensively studied. Along with anti-inflammatory, ${ }^{[10]}$ immunomodulatory ${ }^{[11]}$ and redox-state maintenance bioactivities, ${ }^{[12,13]}$ it has also been reported to have good antimicrobial bioactivity. ${ }^{[14,15]} A$. ferox and $A$. arborescens have also been shown to inhibit the growth of various bacteria associated with wound infections and thus enhance wound healing. ${ }^{[16]}$ Similarly, A. perryi baker has been shown to inhibit the growth of Staphylococcus aureus and Enterococcus faecalis in vitro. ${ }^{[17]}$

Although much of the scientific investigation into the antibacterial properties of Aloe species is dominated by A. barbadensis, A. ferox, $A$. arborescens and $A$. perryi baker, there have been a number of other fruitful investigations into the antibacterial properties of other Aloe species. Aloe chinensis and Aloe succotrina have been reported to be effective against Mycobacterium tuberculosis. ${ }^{\left[{ }^{[8]}\right.}$ Aloe secundiflora has been shown to inhibit Salmonella gallinarum growth ${ }^{[19]}$ and Aloe excelsa inhibits the growth of various bacteria in vitro. ${ }^{[20]}$ This study was undertaken to determine whether other Aloe species display similar antibacterial activities and toxicity as $A$. barbadensis Miller.

\section{MATERIALS AND METHODS}

\section{Plant material \\ Collection of plant samples}

Aloe elgonica, Aloe pruinosa, Aloe chabaudii, Aloe daiyana, Aloe marlothi and Aloe vryheidensis leaves were obtained from Philip Cameron, Senior Botanic Officer, Brisbane Botanical Gardens, Mt Cootha. A. barbadensis leaves were obtained from John Gorringe of Aloe Wellness Australia. Leaves of each species were obtained from single plants, washed in deionized water and processed within 4 hours of collection.

\section{Preparation of crude extracts}

A. elgonica, A. pruinosa, A. chabaudii, A. daiyana, A. marlotbi, A. vryheidensis and $A$. barbadensis leaves were dried in a sunbeam food dehydrator and the dried material was ground to a coarse powder. One gram of each of the dried plant materials was extracted extensively in $50 \mathrm{ml}$ methanol (Ajax, AR grade) for 24 hours at $4^{\circ} \mathrm{C}$ with gentle shaking. The extract was filtered through filter paper (Whatman No. 54) under vacuum, followed by drying by rotary evaporation in an Eppendorf concentrator 5301. The resultant pellet was dissolved in $5 \mathrm{ml}$ deionized water. The extract was passed through $0.22 \mu \mathrm{m}$ filter (Sarstedt, Mawson Lakes, Australia) and stored at $4^{\circ} \mathrm{C}$.

\section{Antibacterial screening Test microorganisms}

All the microbial strains were obtained from Michelle Mendell and Tarita Morais, Griffith University, Australia. Stock cultures of Aeromonas hydrophilia, Alcaligenes faecalis, Bacillus cereus, Citrobacter freundii, Escherichia coli, Klebsiella pneumoniae, Proteus mirabilis, Pseudomonas fluorescens, Salmonella newport, Serratia marcescens, Sbigella sonnei, Sta. aureus, Staphylococcus epidermidis and Streptococcus pyogenes were subcultured and maintained in nutrient broth at $4^{\circ} \mathrm{C}$.

\section{Evaluation of antimicrobial activity}

Antimicrobial activity of all plant extracts was determined using a modified Kirby-Bauer ${ }^{[21]}$ disk diffusion method. Briefly, $100 \mu \mathrm{l}$ of the test bacteria were grown in $10 \mathrm{ml}$ of fresh media until they reached a count of approximately $10^{[8]} \mathrm{cells} / \mathrm{ml}$. Then, $100 \mu \mathrm{l}$ of microbial suspension was spread onto nutrient agar plates.

The Aloe leaf methanolic extracts were tested for antibacterial activity using $5 \mathrm{~mm}$ sterilized filter paper disks. Disks were impregnated with $10 \mu \mathrm{l}$ of the test sample, allowed to dry and placed onto inoculated plates. The plates were allowed to stand at $4^{\circ} \mathrm{C}$ for 2 hours before incubation with the test microbial agents. Plates inoculated with Alcaligenes faecalis, Aeromonas hydrophilia, Bacillus cereus, Citrobacter freundii, Klebsiella pneumoniae, Proteus mirabilis, Psendomonas fluorescens, Serratia marcescens, were incubated at $30^{\circ} \mathrm{C}$ for 24 hours, and then the diameters of the inhibition zones were measured in millimetres. Plates inoculated with Escherichia coli, Salmonella nemport, Sbigella sonnei, Staphylococcus aureus, Staphylococcus epidermidis and Streptococcus pyogenes were incubated at $37^{\circ} \mathrm{C}$ for 24 hours, and then the diameters of the inhibition zones were measured. All measurements were to the closest whole millimeter. Each antimicrobial assay was performed in at least triplicate. Mean values are 
reported in this study. Standard disks of ampicillin $(2 \mu \mathrm{g})$ and chloramphenicol $(10 \mu \mathrm{g})$ were obtained from Oxoid Ltd. and served as positive controls for antimicrobial activity. Filter disks impregnated with $10 \mu \mathrm{l}$ of distilled water were used as a negative control.

\section{Toxicity screening}

\section{Reference toxins for toxicity screening}

Potassium dichromate $\left(\mathrm{K}_{2} \mathrm{Cr}_{2} \mathrm{O}_{7}\right)$ (AR grade, Chem-Supply, Australia) was prepared as a $1.6 \mathrm{mg} / \mathrm{ml}$ solution in distilled water and was serially diluted in artificial seawater for use in the Artemia franciscana nauplii bioassay. Mevinphos (2-methoxycarbonyl-1-methylvinyl dimethyl phosphate) was obtained from Sigma-Aldrich as a mixture of cis (76.6\%) and trans (23.0\%) isomers and prepared as a $4 \mathrm{mg} /$ $\mathrm{ml}$ stock in distilled water. The stock was serially diluted in artificial seawater for use in the bioassay.

\section{Ar. franciscana nauplii toxicity screening}

Toxicity was tested using the $A r$. franciscana nauplii lethality assay developed by Meyer et al. ${ }^{[22]}$ for the screening of active plant constituents with the following modifications. Ar. franciscana Kellogg cysts were obtained from North American Brine Shrimp, LLC, USA (harvested from the Great Salt Lake, Utah). Synthetic seawater was prepared using Reef Salt, AZOO Co, Whittier., USA. Seawater solutions in $34 \mathrm{~g} / 1$ distilled water were prepared prior to use. Two grams of $A r$. franciscana cysts were incubated in 1 1 synthetic seawater under artificial light at $25^{\circ} \mathrm{C}, 2000 \mathrm{Lux}$ with continuous aeration. Hatching commenced within 16-18 hours of incubation. Newly hatched Ar. franciscana (nauplii) were used within 10 hours of hatching. Nauplii were separated from the shells and remaining cysts and were concentrated to a suitable density by placing an artificial light at one end of their incubation vessel and the nauplii rich water closest to the light was removed for biological assays. Exactly $400 \mu \mathrm{l}$ of seawater containing approximately 45 (mean 43.8, $n=145$, SD 18.6) nauplii were added to wells of a 48 -well plate and immediately used for bioassay. The plant extracts were diluted to $3000 \mu \mathrm{g} / \mathrm{ml}$ in seawater for toxicity testing, resulting in a $1500 \mu \mathrm{g} / \mathrm{ml}$ concentration in the bioassay. Four hundred microliters of diluted plant extracts and the reference toxins were transferred to the wells and incubated at $25 \pm 1^{\circ} \mathrm{C}$ under artificial light (1000 Lux). A negative control (400 $\mu \mathrm{l}$ seawater) was run in at least triplicate for each plate. All treatments were performed in at least triplicate. The wells were checked at regular intervals and the number of dead counted. The nauplii were considered dead if no movement of the appendages was observed within 10 seconds. After 72 hours, all the nauplii were sacrificed and counted to determine the total number per well. The $\mathrm{LC}_{50}$ with $95 \%$ confidence limits for each treatment was calculated using probit analysis. ${ }^{[23]}$

\section{RESULTS}

Liquid extraction yields and qualitative phytochemical screening

Extraction of $1 \mathrm{~g}$ of the dried Aloe leaf material with methanol yielded dried plant extracts ranging from 27.8 (A. pruinosa) $\mathrm{mg}$ to $78.2 \mathrm{mg}$ (A. barbadensis) [Table 1]. The dried extracts were resuspended in $5 \mathrm{ml}$ of deionized water resulting in the extract concentrations shown in Table 1.

\section{Antibacterial activity}

Ten microliters of each extract was tested in the disk diffusion assay against a panel of 14 bacteria [Table 2]. Only A. barbadensis displayed antibacterial activity, inhibiting the growth of 8 of the 14 bacteria tested $(57.1 \%)$. It was particularly potent against $A l$. faecalis and Pr. mirabilis as determined from the zone of inhibition $(15.6 \pm 1.5 \mathrm{~mm}$ and $14.3 \pm 1.5 \mathrm{~mm}$, respectively). The A. barbadensis methanolic extract displayed antibacterial activity toward both Gram-positive and Gram-negative bacteria, although Gram-positive bacteria appeared more susceptible. It inhibited the growth of all 4 of the Gram-positive bacteria tested $(100 \%)$. Of the 10 Gramnegative bacteria tested, $4(40 \%)$ were inhibited by the A. barbadensis methanolic extract. In contrast, none of the other Aloe species inhibited the growth of any of the bacteria tested.

Numbers indicate the mean diameters $(\mathrm{mm})$ of inhibition of at least triplicate experiments \pm standard deviation. - Indicates no growth inhibition. Ampicillin $(2 \mu \mathrm{g})$ and chloramphenicol $(10 \mu \mathrm{g})$ were used as the positive controls

\section{Quantification of toxicity}

The Aloe leaf extracts [Figures 1a-g] were diluted to 3000 $\mu \mathrm{g} / \mathrm{ml}$ in artificial seawater for toxicity testing, resulting in a $1500 \mu \mathrm{g} / \mathrm{ml}$ concentration in the Artemia nauplii lethality bioassay. For comparison, the reference toxins potassium dichromate $(800 \mu \mathrm{g} / \mathrm{ml})$ [Figure 1i] and Mevinphos (2000

\begin{tabular}{|c|c|c|}
\hline $\begin{array}{l}\text { Plant leaf } \\
\text { extracted }\end{array}$ & $\begin{array}{l}\text { Mass of dried } \\
\text { extract }(\mathrm{mg})\end{array}$ & $\begin{array}{l}\text { Resuspended } \\
\text { extract } \\
\text { concentration } \\
(\mathrm{mg} / \mathrm{ml})\end{array}$ \\
\hline A. elgonica & 53.8 & 10.8 \\
\hline A. pruinosa & 27.8 & 9.6 \\
\hline A. chabaudii & 32 & 6.4 \\
\hline A. daiyana & 56.4 & 11.2 \\
\hline A. marlothi & 43.2 & 8.6 \\
\hline A. vryheidensis & 69 & 13.8 \\
\hline A. barbadensis & 78.2 & 15.6 \\
\hline
\end{tabular}



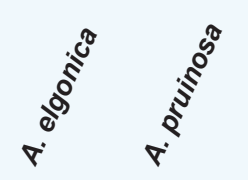
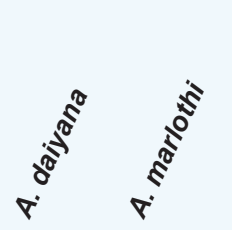
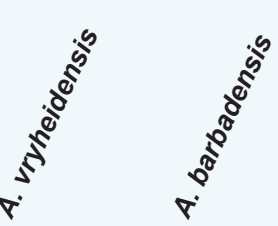

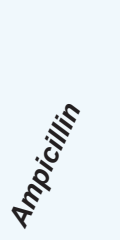

$15.2 \pm 1.2$

$12.0 \pm 1.0$

$8.3 \pm 0.6$

$14.7 \pm 0.6$

$10.3 \pm 0.6$

$17.3 \pm 0.6$

$18.2 \pm 0.5$

$18.7 \pm 0.6$

$0 \pm 0$

$14.0 \pm 0$

$26.7 \pm 0.6$

$11.7 \pm 2.1$

$26.3 \pm 1.5$

$17.0 \pm 1.0$

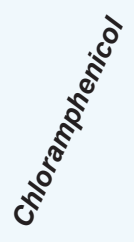

$6.3 \pm 0.6$

$28.7 \pm 1.6$

$15.7 \pm 1.2$

$17.3 \pm 0.6$

$21.3 \pm 1.5$

$8.7 \pm 0.6$

$21.2 \pm 1.2$

$20.3 \pm 0.6$

$14.7 \pm 0.6$

$14.3 \pm 0.6$

$13.3 \pm 1.2$

\section{Gram positive cocci}

Sta. aureus

Sta. epidermidis

Str. pyogenes

$\begin{array}{lllllll}- & - & - & - & - & - & 7.2 \pm 0.6 \\ - & - & - & - & - & - & 6.3 \pm 0.6 \\ - & - & - & - & - & - & 9.0 \pm 1.2\end{array}$

$16.0 \pm 1.0$

$12.3 \pm 0.6$

$24.0 \pm 1.0$

Numbers indicate the mean diameters $(\mathrm{mm})$ of inhibition of at least triplicate experiments \pm standard deviation. - Indicates no growth inhibition. Ampicillin $(2 \mu \mathrm{g})$ and chloramphenicol $(10 \mu \mathrm{g})$ were used as the positive controls

$\mu \mathrm{g} / \mathrm{ml}$ [ [Figure 1j] were also tested in the Ar. franciscana lethality bioassay. Both reference toxins were rapid in their induction of the onset of mortality, inducing mortality within the first 3 hours of exposure. Also, 100\% mortality was evident following 4-5 hours of exposure. Similarly, $A$. barbadensis [Figure 1g] exposure induced mortality rapidly, with $100 \%$ mortality induction achieved by 4 hours. $A$. elgonica [Figure 1a] also induced significant mortality by 24 hours $(80.1 \pm 8.1 \%)$. The induction of mortality reached $100 \%$ by 72 hours. $A$. pruinosa [Figure $1 \mathrm{~b}$ ] and A. daiyana [Figure 1d] also induced mortality significantly above that of the seawater control [Figure $1 \mathrm{~h}$ ] although neither induced $\geq 50 \%$ mortality by 24 hours. Exposure to all other Aloe species [Figures 1c, 1e] resulted in no increase in mortality above that of the seawater control [Figure 1h].

To determine the effect of toxin concentration on the induction of mortality, the extract was serially diluted in artificial seawater to test across the concentration range $2000-100 \mu \mathrm{g} / \mathrm{ml}$ in the Artemia nauplii bioassay at 24, 48 and 72 hours. Table 3 shows the $\mathrm{LC}_{50}$ values of the Aloe leaf extracts toward $A r$. franciscana. No $\mathrm{LC}_{50}$ values are reported for the $A$. pruinosa, $A$. chabaudii, $A$. marlothi and A. vryheidensis leaf extracts at some times as less than $50 \%$ mortality was seen for all concentrations tested at these
Table 3: $\mathrm{LC}_{50}(95 \%$ confidence interval) for brine shrimp nauplii exposed to Aloe extracts or the reference toxins potassium dichromate and Mevinphos

\begin{tabular}{lccc}
\hline Sample & \multicolumn{3}{c}{ LC50 $(\boldsymbol{\mu g} / \mathbf{m l})$ at time } \\
\cline { 2 - 4 } & $\mathbf{2 4}$ hours & $\mathbf{4 8}$ hours & $\mathbf{7 2}$ hours \\
\hline A. elgonica & 1094.3 & 923.9 & 906.8 \\
A. pruinose & - & 1786.7 & 654.5 \\
A. chabaudii & - & - & - \\
A. daiyana & 1018.2 & 517 & 405.7 \\
A. marlothi & - & - & - \\
A. vryheidensis & - & - & - \\
A. barbadensis & 1043 & 904 & 895 \\
Mevinphos & 1320 & 495 & 115 \\
Potassium dichromate & 78 & 14 & 3.9 \\
\hline
\end{tabular}

- Denotes values that were not obtained as $\geq 50 \%$ mortality was not obtained at this time point

test periods. Indeed, all Aloe extracts tested displayed low toxicity $(>1000 \mu \mathrm{g} / \mathrm{ml})$ at 24 hours with $A$. pruinosa showing low toxicity also at 48 hours. $A$. daiyana was the most toxic of the Aloe species at all times tested. Potassium dichromate (24 hour $\mathrm{LC}_{50} 78.0 ; 48$ hour $\mathrm{LC}_{50}$ 14.0; 72 hour $\mathrm{LC}_{50} 3.9$ ) was substantially more toxic than all the Aloe leaf extracts or Mevinphos (24 hour $\mathrm{LC}_{50}$ 1320; 48 hour $\mathrm{LC}_{50} 495 ; 72$ hour $\left.\mathrm{LC}_{50} 115\right)$ at all times tested. 


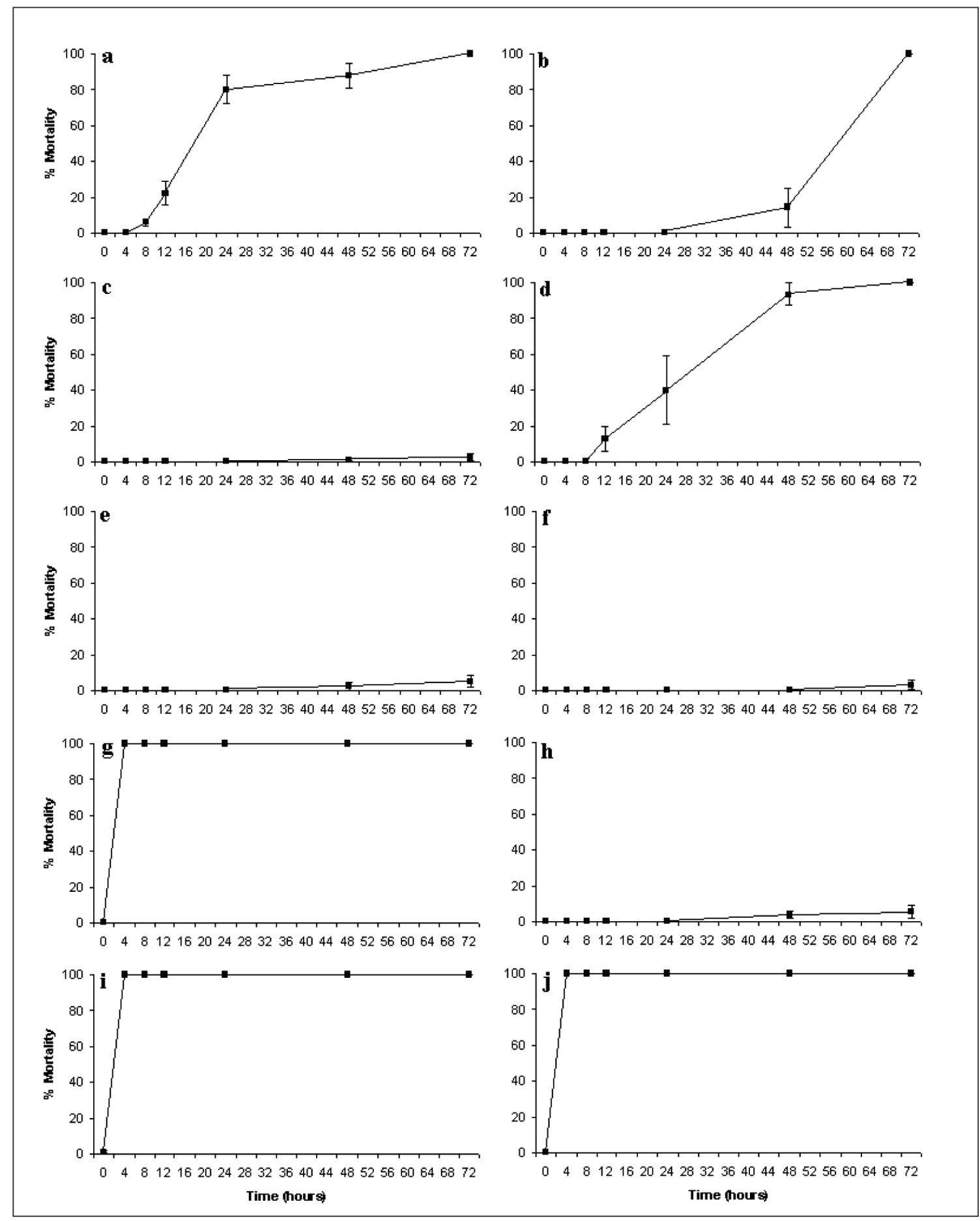

Figure 1: Brine shrimp lethality of (a) A. elgonica methanol extract (1500 $\mu \mathrm{g} / \mathrm{ml})$, (b) A. pruinosa methanol extract (1500 $\mu \mathrm{g} / \mathrm{ml})$, (c) A. chabaudii methanol extract $(1500 \mu \mathrm{g} / \mathrm{ml})$, (d) A. daiyana methanol extract $(1500 \mu \mathrm{g} / \mathrm{ml})$, (e) A. marlothi methanol extract $(1500 \mu \mathrm{g} / \mathrm{ml})$, (f) A. vryheidensis methanol extract $(1500 \mu \mathrm{g} / \mathrm{ml})$, (g) $A$. barbadensis methanol extract $(1500 \mu \mathrm{g} / \mathrm{ml})$, (h) artificial seawater negative control, (i) potassium dichromate $(800 \mu \mathrm{g} / \mathrm{ml})$, (j) Mevinphos $(2000 \mu \mathrm{g} / \mathrm{ml})$. All bioassays were performed in at least triplicate and are expressed as mean \pm standard deviation

\section{DISCUSSION}

In agreement with previously published reports, ${ }^{[14,15]}$ A. barbadensis methanolic extract displayed antibacterial inhibitory activity toward a broad spectrum of bacteria tested in this study. This extract inhibited the growth of both Gram-positive and Gram-negative bacteria although it was more effective at inhibiting Gram-positive bacteria. The greater susceptibility of Gram-positive bacteria seen in this study is in agreement with previously reported results for South American, ${ }^{[24]}$ African ${ }^{[25,26]}$ and Australian ${ }^{[27]}$ plant extracts. The Gram-negative bacterial cell wall outer 
membrane is thought to act as a barrier to many substances including antibiotics. ${ }^{[28]}$ The uptake of the $A$. barbadensis extract antibiotic agents by Gram-negative bacteria is presumably affected by the cell wall outer membrane of some bacteria. Despite the close taxonomic relationship between $A$. barbadensis and the other Aloe species tested in this study, none of the other Aloe extracts displayed any ability to inhibit the growth of any of the bacteria tested.

Whilst individual antibacterial components were not identified in this study, $A$. barbadensis leaf gel and rind are known to contain the anthraquinones aloe emodin and aloin. Scientific studies have demonstrated the antibacterial activity of these anthraquinones ${ }^{[2]}$ although the mechanism of their antibacterial bioactivity has not yet been fully established. Previous studies have reported on the antioxidant and pro-oxidant potential of $A$. barbadensis juice and extracts ${ }^{[12,13,30,31]}$ and the high free radical scavenging activity of aloe emodin and aloin and their ability to inhibit lipid peroxidation. ${ }^{[32]}$

The seemingly conflicting antioxidant/pro-oxidant effects of these anthraquinones may be due to different concentrations present in these studies. Tian and Hua ${ }^{[33]}$ have reported on the concentration-dependent effects of aloin and aloe emodin. Aloin has a pro-oxidant effect at low concentrations and has an antioxidant effect at higher concentrations. In contrast, aloe emodin was shown to function as a pro-oxidant only at high concentrations. Thus, the antibacterial bioactivity associated with the A. barbadensis extract in the current study may be due to a relatively high level of aloe emodin and/or a low concentration of aloin present in the extract. Interactions between the various components within the extract may also play a role in converting otherwise antioxidant molecules into pro-oxidants in the extract or vice versa. It is therefore still possible that aloin and/or aloe emodin are also present in the other Aloe extracts which did not display antibacterial activity in the current study, albeit at concentrations that would confer antioxidant rather than pro-oxidant bioactivities. Their presence/absence in these extracts was not examined in the current report. Further studies are needed to determine whether these compounds are present, and if they are present at concentrations that would favour antioxidant rather than pro-oxidant activity.

Studies within this laboratory have also established the presence of antibacterial coumaroyl chromones in $A$. barbadensis methanolic extracts and have demonstrated their antibacterial potential. ${ }^{[14]}$ Other studies have demonstrated the antimicrobial activity of other chromones from diverse plant species such as Origanum syriacum Lauraceae, ${ }^{[34]}$ Chamaecyparis pisifera ${ }^{[35]}$ and Ferula communis. ${ }^{[36]}$ Budzisz et al. ${ }^{[37]}$ examined the antibacterial activities of various synthetic chromones, finding activity against various bacterial species. The Budzisz study found the synthetic chromones to be particularly active at inhibiting the growth of Gram-positive bacteria. Whether similar chromones are also present in the other Aloe species extracts was not established in the current study and further studies need to focus on the phytochemistry of these extracts. Due to the lack of antibacterial activity of the other Aloe extracts, it is likely that if present, these compounds are in much lower concentrations or are present as inactivated forms. Alternatively, compounds that inhibit their potential antibacterial mechanisms may be present in the other Aloe extracts, but are lacking or in low concentrations in the $A$. barbadensis extract.

\section{CONCLUSIONS}

Methanolic extracts of A. elgonica, A. pruinosa, A. chabaudii, A. daiyana, $A$. marlothi and $A$. vryheidensis displayed no antibacterial activity in the disk diffusion assay despite their close taxonomic relationship with $A$. barbadensis, a plant with well-known antibacterial properties. All Aloe species displayed low toxicity toward Artemia nauplii similar to that of $A$. barbadensis, indicating that the compounds responsible for this toxicity may not be responsible for the antibacterial activity of $A$. barbadensis.

\section{ACKNOWLEDGMENTS}

Financial support for this work was provided by the School of Biomolecular and Physical Sciences, Griffith University, Australia. The authors would like to thank Philip Cameron, Senior Botanic Officer, Brisbane Botanical Gardens, Mt Cootha and John Gorringe of Aloe Wellness Australia for providing the Aloe leaf specimens used in these studies.

\section{REFERENCES}

1. Kamboj VP. Herbal medicine. Curr Sci 2000;78:35-9.

2. Hostettmann K, Hamburger M. Search for new lead compounds of natural origin. In: Testa B, Kyburz E, Fuhrer W, Giger R, editors. Perspectives in Medical Chemistry. Basel: Verlag Helvitica Acta; 1993.

3. Newman DJ, Cragg GM, Snader KM. The influence of natural products on drug discovery. Nat Prod Rep 2000;17:215-34.

4. Walsh G. Biopharmaceuticals: Biochemistry and Biotechnology. $3^{\text {rd }}$ ed. Chinchester: Wiley; 2003.

5. Gilani AH, Rahman AU. Trends in ethnopharmocology. J Ethnopharmacol 2005;100:43-9.

6. Chandana BK, Saxena AK, Shukla S, Sharma N, Gupta DK, Suri KA, et al. Hepatoprotective potential of Aloe Barbadensis mill: Against carbon tetrachloride induced hepatotoxicity. J Ethnopharmacol 2007;111:560-6.

7. Zahn M, Trinh T, Jeong ML, Wang D, Abeysinghe P, Jia Q, et al. A reversed-phase high-performance liquid chromatographic method for the determination of Aloesin: Aloeresin A and Anthraquinone in Aloe ferox. Phytochem Anal 2007;19:122-6. 
8. Morita H, Mizuuchi Y, Abe T, Kohno T, Noguchi H, Abe I. Cloning and functional analysis of a Novel Aldo-Keto reductase from Aloe Arborescens. Biol Pharm Bull 2007;30:2262-7.

9. Eshun K, He Q. Aloe Vera: A valuable ingredient for the food, pharmaceutical and cosmetic industries - a review. Crit Rev Food Sci Nutr 2004;44:91-6.

10. Langmead L, Makins RJ, Rampton DS. Antiifflammatory effects of Aloe vera gel in human colorectal mucosa in vitro. Aliment Pharmacol Ther 2004;19:521-7.

11. Tai-Nin Chow J, Williamson DA, Yates KM, Goux WJ. Chemical characterisation of the immunomodulating polysaccharide of Aloe vera L. Carbohydr Res 2005;340:1131-42.

12. Sirdaarta J, Cock I. Effect of Aloe barbadensis Miller juice on oxidative stress biomarkers in aerobic cells using Artemia franciscana as a model. Phytotherapy Res 2010;24:360-4.

13. Sirdaarta J, Cock I. Vitamin E and Trolox ${ }^{\mathrm{TM}}$ reduce toxicity of Aloe barbadensis miller juice in Artemia franciscana nauplii but individually are toxic at high concentrations. Int J Toxicol 2008;5:1.

14. Cock IE. Antimicrobial activity of Aloe barbadensis Miller leaf gel components. Int J Microbiol 2008;4:2.

15. Ferro VA, Bradbury F, Cameron P, Shakir E, Rahman SR, Stimson WH. In vitro susceptibilities of Shigella flexneri and Streptococcus pyogenes to inner gel of Aloe barbadensis Miller. Antimicrob Agents Chemother 2003;47:1137-9.

16. Jia Y, Zhao G, Jia J, Preliminary evaluation: The effects of Aloe ferox Miller and Aloe arborescens Miller on wound healing. J Ethnopharmacol 2008;120:181-9.

17. Awadh Ali NA, Jülich WD, Kusnick C, Lindequist U. Screening of Yemeni medicinal plants for antibacterial and cytotoxic activities. J Ethnopharmacol 2001;74:173-9.

18. Gottshall RY, Lucas EH, Lickfeldt A, Roberts JM. The occurance of antibacterial substances active against Mycobacterium tuberculosis in seed plants. J Clin Invest 1949;28:920-3.

19. Waihenya RK, Mtambo MM, Nkwengulila G, Minga UM. Efficacy of crude extract of Aloe secundiflora against Salmonella gallinarum in experimentally infected free-range chickens in Tanzania. J Ethnopharmacol 2002;79:317-23.

20. Coopoosamy RM, Magwa ML. Antibacterial activity of chrysophanol isolated from Aloe excelsa (Berger). Afr J Biotechnol 2006;5:16.

21. Bauer AW, Kirby WM, Sherris JC, Turck M. Antibiotic susceptibility testing by a standardized single disk method. Am J Clin Pathol 1966;45:493-6.

22. Meyer BN, Ferrigni NR, Putnam JE, Jacobsen LB, Nichols DE, McLaughlin JL. Brine shrimp: A convenient general bioassay for active plant constituents. Planta Medica 1982;45:31-4.

23. Finney DJ. Probit Analysis. $3^{\text {rd }}$ ed. Cambridge: Cambridge University Press; 1971.
24. Paz EA, Cerdeiras MP, Fernandez J, Ferreira F, Moyna P, Soubes M, et al. Screening of Uruguayan medicinal plants for antimicrobial activity. J Ethnopharmacol 1995;45:67-70.

25. Kudi AC, Umoh JU, Eduvie LO, Gefu J. Screening of some Nigerian medicinal plants for antibacterial activity. J Ethnopharmacol 1999;67:225-8.

26. Vlietinck AJ, van Hoof L, Totte J, Lasure A, Vanden Berghe D, Rwangabo PC, et al. Screening of a hundred Rwandese medicinal plants for antimicrobial and antiviral properties. J Ethnopharmacol 1995;46:31-47.

27. Palombo EA, Semple SJ. Antibacterial activity of traditional Australian medicinal plants. J Ethnopharmacol 2001;77:151-7.

28. Tortora GJ, Funke BR, Case CL. Microbiology: An Introduction. San Francisco: Benjamin Cummings; 2001.

29. Wu YW, Ouyang J, Xiao XH, Gao WY, Liu Y. Antimicrobial properties and toxicity of anthraquinones by microcalorimetric bioassay. Chinese J Chem 2006;24:45-50.

30. $\mathrm{Hu} \mathrm{Q}, \mathrm{Hu} \mathrm{Y}, \mathrm{Xu}$ J. Free radical-scavenging activity of Aloe vera (Aloe barbadensis Miller) extracts by supercritical carbon dioxide extraction. Food Chem 2005;91:85-90.

31. $\mathrm{Hu}, \mathrm{X}, \mathrm{Xu}, \mathrm{Hu} \mathrm{Q}$. Evaluation of Antioxidant potential of Aloe vera (Aloe barbadensis Miller) extracts. J Agric Food Chem 2003;51:7788-791.

32. Malterud KE, Farbrot TL, Huse AE, Sund RB. Antioxidant and radical scavenging effects of anthraquinones and anthrones. Pharmacology 1993;47:77-85.

33. Tian B, Hua Y. Concentration-dependence of prooxidant and antioxidant effects of aloin and aloe-emodin on DNA. Food Chem 2005;91:413-8.

34. Alma MH, Mavi A, Yildirim A, Digrak M, Hirata T. Screening chemical composition and in vitro antioxidant and antimicrobial activities of the essential oils from Origanum syriacum L. growing in Turkey. Bio Pharm Bull 2003;26:1725-9.

35. Xiao D, Kuroyanagi M, Itani T, Matsuura H, Udayama M, Murakami $\mathrm{M}$, et al. Studies on constituents from Chamaecyparis pisifers and antibacterial activity of diterpenes. Chem Pharm Bull (Tokyo) 2001;49:1479-81.

36. Al-Yahya M, Muhammad I, Mirza HH, El-Feraly FS. Antibacterial constituents from the rhizomes of Ferula communis. Phytother Res 1998;12:335-9.

37. Budzisz E, Nawrot E, Malecka M. Synthesis, antimicrobial, and alkylating properties of 3-phosphonic derivatives of chromone. Arch Pharm Med Chem 2001;334:381-7.

Source of Support: Nil, Conflict of Interest: Nil 